\title{
Variation in fibre properties of cultivated Siberian larch (Larix sibirica Ledeb.) in relation to radial and axial locations in the trunk
}

\author{
Katri Luostarinen
}

Received: 16 November 2010 / Accepted: 21 February 2011 / Published online: 1 July 2011

(C) INRA and Springer Science+Business Media B.V. 2011

\begin{abstract}
- Introduction As the major resources of Siberian larch planted in Finland will be at a harvestable age in the near future, knowledge concerning wood and fibre properties of cultivated larches is needed. The properties affect both the character of pulp and paper, as well as properties important in the structural usage.

- Objectives The aim of this study was to compare fibre length, width and coarseness from different locations in the trunk and to study the relationships of the fibre properties with basic wood properties (density, ring width and proportion of latewood).

- Results Enlargement in fibre dimensions, particularly in coarseness, could be observed to an exceptionally large extent in the radial direction. Changes in the relationship between fibre length and ring width occurred at quite an early stage, around 60 years from the pith.

- Discussion Fibre dimensions were smaller in the studied planted larches than in larches grown in their natural provenances. Furthermore, changes in wood properties at 60 years from the pith may be due to genetic factors, fast growth or senescence of the studied trees. The very large differences in the fibre dimensions in the radial direction may affect the suitability of cultivated fast grown Siberian larch wood for different usages.
\end{abstract}

Keywords Coarseness · Fibre length · Fibre width · Juvenile wood Mature wood

Handling Editor: Jean-Michel Leban

K. Luostarinen $(\bowtie)$

School of Forest Sciences, University of Eastern Finland,

Box 111, FI-80101 Joensuu, Finland

e-mail: katri.luostarinen@uef.fi

\section{Introduction}

Siberian larch (Larix sibirica Ledeb.) is the most planted exotic tree species in Finland with a planted area of more than 20,000 ha since the 1960s (Silander et al. 2000). Considerable areas of these plantations are now at the age when the first thinning should be performed (Verkasalo 1993, 2001). Accordingly, the possibilities regarding the uses of the larch wood is currently being discussed, addressing the technical challenges involved (Saimovaara 2001).

When Siberian larch is cultivated in Finland, fertile sites, for example former fields, are recommended because at such sites the species grows generally faster than domestic softwoods (i.e. Pinus sylvestris L., Picea abies (L.) H. Karst.) (Vuokila 1960). Growing the species in fertile places emphasises its fast growth, particularly when the trees are young, and, thus, increases the amount of juvenile wood (Zobel and Sprague 1998). Juvenile wood is a significant problem, particularly if the growth rate has been fast. This relates particularly the main uses of larch wood, which are structural ones (Lyck and Bergstedt 2007). In larch, juvenile wood differs greatly from mature wood, because, for example, the proportion of earlywood is higher (Isebrands and Hunt 1975; Karlman et al. 2005), additionally it shows considerably more distortion than mature wood (Luostarinen and Heikkonen 2011). Furthermore, large colour differences between heartwood and sapwood are clear (Lyck and Bergstedt 2007). They may provide a lively outlook, but they can cause problems if being used for decorative purposes. In the pulp and paper industries, the main problem in using larch wood is connected with the coloured extractives, the amount of which is high in the heartwood (Côté and Timell 1967), because they increase 
the amount of chemicals needed in pulping and bleaching (Lyck and Bergstedt 2007; Valade 1998). In addition, high concentration of extractives decreases the proportion of cellulose from ca. $53 \%$ of sapwood to $43 \%$ of heartwood (Hutorščikov 1959). However, fast growth in larch may even increase the yield of cellulose in pulping (Petrik 1968). Conversely, commonly high density and large amount of energy-rich extractives in larch wood are beneficial in its use as bioenergy; however, this usage, by itself, is not profitable for larch.

In pulp and paper, the properties of fibres are of great importance, while in the structural wood industries properties of fibres affect density, strength (Zhang and Morgenstern 1995) and deformations (Luostarinen and Heikkonen 2011). It is well known that fibre properties are not similar in all parts of the tree trunk. In the radial direction, the clearest change can be seen in the dimensions of the fibres: fibres both get longer and wider from pith to bark. In addition, differences in wood anatomy can be observed between different heights in the trunk but they are smaller than radial differences. Generally, fibre length increases from the butt to the height of a few metres, subsequently decreasing towards the top of the tree (Zobel and van Buijtenen 1989). However, little is known about the distributions of fibres according to their length or width in different radial and axial positions, as is the case for all wood species (Herman et al. 1998; Utunen 2008; Zubizarreta et al. 2008). This is despite the fact that not only the mean fibre length and width particularly affect paper properties, but also the distribution of fibres of different dimensions (Lindholm and Kettunen 1983). If the know-how about fibre distributions was available, pulp and paper properties could be better controlled by sorting pulpwood according to fibre properties (Spångberg 1999).
The aim of this study was to investigate the variation in the fibre properties, i.e. fibre length (FL), fibre width (FW) and coarseness (C), both in radial and axial directions in fast grown Larix sibirica trees planted in Finland outside of the natural provenance of the species. In addition, distributions of FL and FW from pith to bark at three different heights in the trunks were studied. Furthermore, properties important regarding structural uses (density, annual ring structure; results from the same trees presented in Luostarinen (2011); Table 1) are correlated with the fibre properties to determine the relationships between them.

\section{Materials and methods}

A total of 16 Siberian larch (L. sibirica Ledeb.) trees were felled in December 2005 from the plantations of the Finnish Forest Research Institute, Punkaharju, Eastern Finland $\left(61^{\circ} 81^{\prime} \mathrm{N}, 29^{\circ} 32^{\prime} \mathrm{E}\right)$, from the Heikinheimo stand of Raivola provenance. The Raivola provenance has been one of the best cultivated in Finland based on growth, its resistance against many kinds of damages and the shape of trunk (Silander et al. 2000; Vuokila 1960). The plantation was established in 1924 with 4year-old seedlings. Thus, the trees were 85 years old when harvested, with breast height diameter of $41.8 \pm 1.1 \mathrm{~cm}$ (standard error of the mean, SE). The trees were felled in connection with a project at Mikkeli University of Applied Sciences regarding Siberian larch timber (Heikkonen et al. 2007). For the purpose of this study, directly following felling, cross-cut discs (thickness $5 \mathrm{~cm}$ ) were sawn from the butt of the trees and from the heights of 4.5 and $9.0 \mathrm{~m}$. Only the part of trunk that had no branches
Table 1 Averages \pm standard errors of the mean of densities (at moisture content of 12\%), ring widths and proportions of latewood by height and wood age class (years from the pith)

\begin{tabular}{lllccc}
\hline Height & Wood age, years & $N$ & Density, $\mathrm{kg} / \mathrm{m}^{3}$ & Ring width, mm & Proportion of latewood, \% \\
\hline Butt & $1-5$ & 16 & $386.4 \pm 12.3$ & $3.4 \pm 0.3$ & $38.5 \pm 1.7$ \\
& $15-20$ & 16 & $418.1 \pm 11.4$ & $4.2 \pm 0.3$ & $39.5 \pm 2.2$ \\
& $21-40$ & 14 & $454.0 \pm 10.3$ & $2.2 \pm 0.2$ & $48.5 \pm 1.9$ \\
& $41-60$ & 9 & $476.7 \pm 11.9$ & $2.6 \pm 0.3$ & $54.5 \pm 2.0$ \\
& $61-73$ & 9 & $454.1 \pm 12.8$ & $3.0 \pm 0.3$ & $54.1 \pm 2.7$ \\
$4.5 \mathrm{~m}$ & $1-5$ & 16 & $375.9 \pm 13.7$ & $6.6 \pm 0.4$ & $23.9 \pm 2.3$ \\
& $15-20$ & 16 & $426.7 \pm 8.8$ & $2.7 \pm 0.2$ & $45.3 \pm 2.1$ \\
& $21-40$ & 16 & $453.1 \pm 8.7$ & $1.8 \pm 0.1$ & $48.5 \pm 1.6$ \\
& $41-60$ & 15 & $474.0 \pm 8.0$ & $1.6 \pm 0.1$ & $54.2 \pm 1.4$ \\
& $61-73$ & 1 & 445.2 & 2.3 & 49.7 \\
$9.0 \mathrm{~m}$ & $1-5$ & 16 & $360.5 \pm 8.2$ & $6.3 \pm 0.4$ & $20.2 \pm 1.0$ \\
& $15-20$ & 16 & $417.3 \pm 5.9$ & $3.0 \pm 0.2$ & $42.4 \pm 1.3$ \\
& $21-40$ & 19 & $440.5 \pm 8.1$ & $1.9 \pm 0.1$ & $49.7 \pm 1.9$ \\
\hline
\end{tabular}


(neither living nor dead) providing logs of grade A, thus suitable for good quality carpenters' products, was investigated.

A strip of $5 \mathrm{~mm}$ in thickness and $20 \mathrm{~mm}$ in width was sawn from pith to bark from each disc. The strips were randomly sawn from any direction from pith to bark to include the natural variation of wood material in different directions in the trunk. The maximum SE achieved with this procedure was approximately $4.2 \%$ (for C, age $15-$ 20 years from the pith, butt; see Table 2). The fibre samples were taken from the strips from four distances from the pith. The first sample was taken from the rings $1-5$ years from the pith, and the second from the rings 15-20 years from the pith from each disc. Because the discs were of different diameters, particularly between the heights, the third sample was taken from the middle of the heartwood and the fourth from the bark side of the heartwood, both consisting of 10 annual rings. Sapwood was not included, because it was commonly very narrow, less than 10 rings, and because both outermost heartwood and sapwood are mature at these ages from the pith (Zobel and Sprague 1998). Thus, it is very unlikely that clear differences in fibre dimensions could have been observed between sapwood and outermost heartwood. The wood of 1-5 years of age from pith represented juvenile wood, 15-20 years maturing wood and others mature wood. For statistical calculations, the samples were classified into five groups according to the age from the pith $(1-5,15-20,21-40$, 41-60 and 61-73 years).
The wood samples were macerated in a solution of acetic acid and peroxide $(1: 1)$ for $24 \mathrm{~h}$ at $60^{\circ} \mathrm{C}$. Following maceration, the cells were separated with a glass rod in a small volume of water and washed to remove all the macerating solution. FL and FW of at least 4,000 fibres/ sample, most often ca. 6,000, average of them being the result of a sample, were then measured using a Fiber Tester (AB Lorenzen \& Wettre, Kista, Sweden). The measurement method of the Fiber Tester is based on image analysis: the device photographs fibres flowing in water in a narrow space between two glass sheets. FLs and FWs are then measured from the photographs. The results, which are the length weighted averages of the measured fibres, are presented according to FL classes determined beforehand. In this study, the determined FL classes were $0.1-0.5,0.51-$ $1.50,1.51-3.0$ and $>3.0 \mathrm{~mm}$. In addition, the device calculates C (weight per unit fibre length, $\mu \mathrm{g} / \mathrm{m}$; see Karlsson 2006).

Statistical analyses were carried out using SPSS 16.0 software. The averages of FL, FW and C were compared radially and axially using general linear model (GLM) multivariate analysis. The pairwise comparisons of fibre properties between heights, as well as between radial locations, were performed using the Scheffe or Tamhane test of the GLM procedure. The Scheffe test was used when the presumptions of parametric tests came true, and the Tamhane test when not. Pearson correlation procedure of SPSS software was used for calculating the correlations between fibre properties and density, ring width, and

Table 2 Averages \pm standard errors of the mean of fibre lengths, fibre widths and coarsenesses by height and wood age class (years from the pith)

\begin{tabular}{|c|c|c|c|c|c|}
\hline Height & Wood age (years) & $N$ & Fibre length (mm) & Fibre width $(\mu \mathrm{m})$ & Coarseness $(\mu \mathrm{g} / \mathrm{m})$ \\
\hline \multirow[t]{5}{*}{ Butt } & $1-5$ & 16 & $1.06 \pm 0.04 \mathrm{aA}$ & $25.5 \pm 0.5 \mathrm{aA}$ & $130.3 \pm 5.0 \mathrm{a}$ \\
\hline & $15-20$ & 16 & $1.99 \pm 0.06 \mathbf{b A}$ & $33.1 \pm 0.4 \mathrm{bA}$ & $245.6 \pm 10.4 \mathrm{bA}$ \\
\hline & $21-40$ & 14 & $2.36 \pm 0.04 \mathrm{cA}$ & $37.2 \pm 0.5 \mathrm{c}$ & $312.4 \pm 8.2 \mathrm{cA}$ \\
\hline & $41-60$ & 9 & $2.29 \pm 0.05 \mathrm{cA}$ & $36.5 \pm 0.6 \mathrm{cA}$ & $303.9 \pm 9.4 \mathrm{cA}$ \\
\hline & $61-73$ & 9 & $2.15 \pm 0.07 \mathbf{b c}$ & $36.5 \pm 0.7 \mathrm{c}$ & $286.5 \pm 9.9 \mathrm{bc}$ \\
\hline \multirow[t]{5}{*}{$4.5 \mathrm{~m}$} & $1-5$ & 16 & $1.17 \pm 0.04 \mathrm{aAB}$ & $26.7 \pm 0.3 \mathrm{aAB}$ & $123.5 \pm 2.8 \mathbf{a}$ \\
\hline & $15-20$ & 16 & $2.61 \pm 0.05 \mathrm{bB}$ & $36.2 \pm 0.5 \mathrm{bB}$ & $288.5 \pm 8.5 \mathrm{bB}$ \\
\hline & $21-40$ & 16 & $3.01 \pm 0.04 \mathbf{c B}$ & $38.2 \pm 0.4 \mathrm{c}$ & $351.0 \pm 7.7 \mathrm{cB}$ \\
\hline & $41-60$ & 15 & $2.97 \pm 0.12 \mathbf{c B}$ & $39.1 \pm 0.5 \mathrm{cB}$ & $343.1 \pm 13.1 \mathrm{bcA}$ \\
\hline & $61-73$ & 1 & 3.33 & 39.2 & 429.9 \\
\hline \multirow[t]{4}{*}{$9.0 \mathrm{~m}$} & $1-5$ & 16 & $1.28 \pm 0.03 \mathrm{aB}$ & $27.6 \pm 0.3 \mathrm{aB}$ & $136.0 \pm 3.8 \mathbf{a}$ \\
\hline & $15-20$ & 16 & $2.61 \pm 0.04 \mathrm{bB}$ & $36.2 \pm 0.6 \mathrm{bB}$ & $291.2 \pm 5.7 \mathbf{b B}$ \\
\hline & $21-40$ & 19 & $3.01 \pm 0.04 \mathrm{cB}$ & $38.2 \pm 0.5 \mathrm{c}$ & $340.7 \pm 7.0 \mathrm{cB}$ \\
\hline & $41-60$ & 13 & $3.22 \pm 0.06 \mathrm{~dB}$ & $40.2 \pm 0.6 \mathrm{~dB}$ & $388.9 \pm 10.0 \mathrm{~dB}$ \\
\hline
\end{tabular}

Different lowercase letters mean significant differences (at 0.05 level) between wood ages from the pith at the given height and different capitals mean significant differences (at 0.05 level) in wood of same cambial age between heights. When the letter is written in bold, the test used was the Tamhane, otherwise it was Scheffe. Because there is only one observation for the wood of cambial age of 61-73 years at the height of $4.5 \mathrm{~m}$, this age/height class was not included in the statistical analyses even though the averages are presented 
proportion of latewood (LW\%; Table 1). The results of the density and annual ring measurements used in this study are explained in detail in Luostarinen (2011).

\section{Results}

3.1 Fibre properties by age from the pith and height in the trunk

Both measured the fibre properties, FL and FW, acted as expected: their dimensions got bigger from the pith towards the bark (Table 2). Mean FL was little more than $1 \mathrm{~mm}$ in the five youngest annual rings near the pith, then increasing clearly by the age of 15-20 years, and reaching the maximum of $2-3 \mathrm{~mm}$ at the age of $21-40$ years from the pith. Furthermore, FW increased from 25-27 $\mu \mathrm{m}$ for the youngest wood to $37-38 \mu \mathrm{m}$ by the age of $21-40$ years from the pith. As C is calculated using both FL and FW, it had a similar trend to the measured properties (Table 2).

FL differed between heights in the trunk so that fibres were shorter at the butt than at the heights of 4.5 and $9.0 \mathrm{~m}$, the difference apparently growing from the pith to the bark (Table 2). Between the two upper heights, no difference was observed. At the butt the maximum FL, $2.36 \mathrm{~mm}$, was observed at the age of 21-40 years from the pith and the maximum FL at the height of $4.5 \mathrm{~m}$, ca. $3 \mathrm{~mm}$, was reached at the same age. At the height of $9.0 \mathrm{~m}$, maximum FL, $3.22 \mathrm{~mm}$, was reached at the age of 41-60 years from the pith. In addition, FW differed between the heights (Table 2). Fibres were narrowest at the butt with significant differences with other heights in juvenile and maturing wood as well as in the wood with age of 41-60 years from the pith. The widening of the fibres continued up to the age of 21-40 years from the pith at the butt and at the height of $4.5 \mathrm{~m}$, but up to age of 41-60 years from the pith at the height of $9.0 \mathrm{~m}$.

Differences in $\mathrm{C}$ between the heights were very similar to those in FL (Table 1). C ranged from ca. $120-130 \mu \mathrm{g} / \mathrm{m}$ of juvenile wood to ca. $390 \mu \mathrm{g} / \mathrm{m}$ in the mature wood located at the height of $9.0 \mathrm{~m}$. Thus, the fibres were coarsest at the height of $9.0 \mathrm{~m}$, and least coarse at the butt height. Significant differences in $\mathrm{C}$ were observed at the age of 140 years from the pith between the height of the butt and both 4.5 and $9.0 \mathrm{~m}$, and at the age 41-60 years from the pith between the heights of 9.0 and both butt and $4.5 \mathrm{~m}$.

\subsection{Length and width distributions of fibres}

The distributions of fibres by length (percentage of fibres in different FL classes) differed particularly between ages from the pith, but also between heights (Table 3). Fibres of the two shortest classes dominated in the juvenile wood, even though at the two upper heights, 4.5 and $9.0 \mathrm{~m}$, the proportion of the FL class $1.51-3.0 \mathrm{~mm}$ clearly exceeded that of the wood located at the butt height. Furthermore, the proportion of the fibres of the FL class $1.51-3.0 \mathrm{~mm}$ dominated in the mature wood at the butt height, but the dominating FL class higher up the trunk was the class $>3.0 \mathrm{~mm}$. This class was almost lacking from the juvenile wood of the butt height, and its proportion was small in juvenile wood higher up the trunk.

Concerning the average FW in each FL class, the shortest fibres were the narrowest, while the longest ones were the widest (Table 3). The only exception was the FW of the fibres over $3 \mathrm{~mm}$ in length of the youngest wood located at the butt: they were narrower than the fibres of the FL classes 0.51-1.5 and 1.51-3.00 mm. However, the SE of FW was also large in the longest FL class. In addition, the FW of the shortest fibres remained similar from the pith to the outermost heartwood, while in the other FL classes the FW increased slightly along with the maturing of the wood.

\subsection{Correlations between fibre properties and wood properties}

The relationships between the studied fibre properties and density, ring width and LW\% were similar at each height (Table 4). The only exception was that between FW and annual ring width at the butt, where it was not significant. Density and LW\% correlated positively with FL, FW and C, while ring width correlated negatively with the fibre properties.

Some correlations between the fibre properties and wood density, annual ring width and LW\% were observed in different wood types (Table 5). The longer the fibres were, the narrower the annual rings in maturing and mature wood. In addition, the longer the fibres were, the larger $\mathrm{LW} \%$ was in the juvenile and maturing wood but the correlation coefficients became negative, though insignificant, in the mature wood. Furthermore, the wider the fibres were, the lower the density and LW\%, and the wider the rings in the juvenile wood, while in the maturing wood the correlation between FW and density became positive, and no correlation was observed in the mature wood. In addition, the wider the fibres were, the narrower the annual rings in the maturing and mature wood. Finally, the higher $\mathrm{C}$ was, the higher the density and LW\% were at the ages 15-40 years from the pith, while the narrower the annual rings were at the ages $15-60$ years from the pith.

\section{Discussion}

In this study the fibres were $17-24 \%$ and $54-61 \%$ shorter at the butt than higher up the trunk, in the juvenile wood and in the mature wood, respectively. So the axial difference was at its smallest in the juvenile wood, increasing towards 
Table 3 The distributions of fibres of different lengths \pm standard error of the mean (percentage of fibres in different FL classes) in different wood age classes (years from the pith) and heights $(\mathrm{m})$ and average widths of fibres \pm standard error of the mean $(\mu \mathrm{m})$ in different $\mathrm{FL}$ classes by wood age class (years from the pith) and height (m)

\begin{tabular}{|c|c|c|c|c|c|c|}
\hline \multirow[t]{2}{*}{ Height } & \multirow{2}{*}{$\begin{array}{l}\text { Wood age } \\
\text { Years }\end{array}$} & \multirow[t]{2}{*}{$N$} & \multicolumn{4}{|c|}{ Fibre length class } \\
\hline & & & $0.1-0.5 \mathrm{~mm}$ & $0.51-1.5 \mathrm{~mm}$ & $1.51-3.0 \mathrm{~mm}$ & $>3.0 \mathrm{~mm}$ \\
\hline \multicolumn{7}{|c|}{$\begin{array}{l}\text { The distributions of fibres of different lengths } \pm \text { standard error of the mean (percentage of fibres in different FL classes) in different wood age } \\
\text { classes (years from the pith) and heights }(\mathrm{m})\end{array}$} \\
\hline \multirow[t]{5}{*}{ Butt } & $1-5$ & 16 & $20.9 \pm 2.4$ & $55.2 \pm 2.5$ & $23.7 \pm 2.4$ & $0.2 \pm 0.0$ \\
\hline & $15-20$ & 16 & $14.5 \pm 1.0$ & $13.0 \pm 1.0$ & $59.1 \pm 1.6$ & $13.4 \pm 2.6$ \\
\hline & $21-40$ & 14 & $11.9 \pm 0.8$ & $10.2 \pm 0.6$ & $45.4 \pm 2.1$ & $32.5 \pm 2.1$ \\
\hline & $41-60$ & 9 & $12.5 \pm 0.8$ & $10.3 \pm 0.8$ & $48.7 \pm 2.6$ & $28.5 \pm 2.9$ \\
\hline & $61-73$ & 9 & $13.9 \pm 1.0$ & $12.0 \pm 1.1$ & $51.5 \pm 3.2$ & $22.6 \pm 3.8$ \\
\hline \multirow[t]{5}{*}{$4.5 \mathrm{~m}$} & $1-5$ & 16 & $20.9 \pm 1.0$ & $47.2 \pm 1.7$ & $31.2 \pm 2.4$ & $0.7 \pm 0.2$ \\
\hline & $15-20$ & 16 & $11.4 \pm 0.7$ & $8.5 \pm 0.4$ & $34.0 \pm 2.1$ & $46.1 \pm 2.5$ \\
\hline & $21-40$ & 16 & $10.4 \pm 0.7$ & $7.2 \pm 0.3$ & $21.6 \pm 1.0$ & $60.8 \pm 1.1$ \\
\hline & $41-60$ & 15 & $12.2 \pm 1.7$ & $9.2 \pm 1.4$ & $21.4 \pm 1.3$ & $57.2 \pm 3.6$ \\
\hline & $61-73$ & 1 & 6.9 & 6.2 & 17.6 & 69.3 \\
\hline \multirow[t]{4}{*}{$9.0 \mathrm{~m}$} & $1-5$ & 16 & $19.5 \pm 0.7$ & $41.3 \pm 1.7$ & $38.3 \pm 2.0$ & $0.9 \pm 0.1$ \\
\hline & $15-20$ & 16 & $11.8 \pm 0.8$ & $8.1 \pm 0.5$ & $33.5 \pm 1.4$ & $46.6 \pm 1.8$ \\
\hline & $21-40$ & 19 & $11.1 \pm 0.6$ & $6.7 \pm 0.2$ & $21.1 \pm 0.8$ & $61.1 \pm 1.0$ \\
\hline & $41-60$ & 13 & $9.9 \pm 0.5$ & $6.4 \pm 0.5$ & $18.2 \pm 1.1$ & $65.5 \pm 1.5$ \\
\hline \multicolumn{7}{|c|}{ Average widths of fibres \pm standard error of the mean $(\mu \mathrm{m})$ in different FL classes by wood age class (years from the pith) and height $(\mathrm{m})$} \\
\hline \multirow[t]{5}{*}{ Butt } & $1-5$ & 16 & $23.1 \pm 0.5$ & $25.3 \pm 0.5$ & $28.0 \pm 0.5$ & $24.1 \pm 3.0$ \\
\hline & $15-20$ & 16 & $22.0 \pm 0.1$ & $32.1 \pm 0.4$ & $35.4 \pm 0.4$ & $35.3 \pm 0.6$ \\
\hline & $21-40$ & 14 & $22.9 \pm 0.2$ & $34.6 \pm 0.4$ & $38.6 \pm 0.5$ & $41.2 \pm 0.7$ \\
\hline & $41-60$ & 9 & $22.6 \pm 0.4$ & $34.4 \pm 0.5$ & $38.0 \pm 0.6$ & $40.2 \pm 1.0$ \\
\hline & $61-73$ & 9 & $22.9 \pm 0.4$ & $34.9 \pm 0.6$ & $38.6 \pm 0.9$ & $41.3 \pm 1.4$ \\
\hline \multirow[t]{5}{*}{$4.5 \mathrm{~m}$} & $1-5$ & 16 & $22.8 \pm 0.1$ & $26.3 \pm 0.2$ & $29.5 \pm 0.3$ & $32.2 \pm 1.0$ \\
\hline & $15-20$ & 16 & $21.8 \pm 0.2$ & $33.7 \pm 0.5$ & $37.0 \pm 0.5$ & $40.0 \pm 0.6$ \\
\hline & $21-40$ & 16 & $22.4 \pm 0.2$ & $34.6 \pm 0.3$ & $38.4 \pm 0.5$ & $41.4 \pm 0.6$ \\
\hline & $41-60$ & 15 & $23.2 \pm 0.3$ & $35.5 \pm 0.7$ & $39.9 \pm 1.0$ & $43.3 \pm 1.2$ \\
\hline & $61-73$ & 1 & 22.5 & 34.5 & 39.0 & 41.3 \\
\hline \multirow[t]{4}{*}{$9.0 \mathrm{~m}$} & $1-5$ & 16 & $22.7 \pm 0.1$ & $27.0 \pm 0.3$ & $30.7 \pm 0.3$ & $32.7 \pm 0.5$ \\
\hline & $15-20$ & 16 & $21.8 \pm 0.2$ & $33.8 \pm 0.5$ & $37.2 \pm 0.6$ & $39.9 \pm 0.7$ \\
\hline & $21-40$ & 19 & $22.2 \pm 0.2$ & $34.7 \pm 0.3$ & $38.6 \pm 0.5$ & $41.4 \pm 0.6$ \\
\hline & $41-60$ & 13 & $22.9 \pm 0.3$ & $35.0 \pm 0.3$ & $39.7 \pm 0.5$ & $43.3 \pm 0.8$ \\
\hline
\end{tabular}

the bark. Chui and MacKinnon-Peters (1995) also observed in several larch species that fibres were clearly shortest at the butt height while at the other heights they did not differ from each other. The increase of FL from the butt upwards is due to ageing of the apical meristem and its effect on cambial initials (Dodd 1988). The mean FLs measured from 4.5 to $9.0 \mathrm{~m}$ height from the trunks in this study were near to those mentioned in Use of larch as raw material for pulp and paper industry (1971) and by Martinsson and Lesinski (2007), though they were, however, clearly shorter than those measured by Koizumi et al. (2003) for Siberian larches grown in Siberia, particularly at the oldest studied ages from the pith. As in Siberia, the larch trees have been observed to grow slower (Karlman et al. 2005; Koizumi et al. 2003) than the studied larches (Luostarinen 2011), the difference in FL between Siberian grown trees and the planted trees used in this study was in accordance with the observations made regarding the relationship between growth rate and FL in several softwoods: in narrow annual rings, the fibres get longer than in wide annual rings (Herman et al. 1998; Nekhaichuk and Bryantseva 1984; Use of larch as raw material for pulp and paper industry 1971; Utunen 2008). This correlation did not occur in the outermost studied wood; however, perhaps because cambium had reached an age in which senescence starts: senescence decreases the lengthening of cambial initials (Bannan 1967). 
Table 4 Pearson correlation coefficients between fibre length (FL), fibre width (FW) and coarseness (C), and density (D), average annual ring width (RW) and proportion of latewood (LW\%) by height

\begin{tabular}{lllll}
\hline & Height & Butt & $4.5 \mathrm{~m}$ & \multicolumn{1}{c}{$9.0 \mathrm{~m}$} \\
& $N$ & 64 & 64 & \multicolumn{1}{c}{64} \\
\hline \multicolumn{2}{c}{ Compared factors } & & & \\
FL & D & $0.599^{\mathrm{a}}$ & $0.650^{\mathrm{a}}$ & $0.762^{\mathrm{a}}$ \\
& RW & $-0.358^{\mathrm{a}}$ & $-0.862^{\mathrm{a}}$ & $-0.917^{\mathrm{a}}$ \\
& LW\% & $0.530^{\mathrm{a}}$ & $0.805^{\mathrm{a}}$ & $0.887^{\mathrm{a}}$ \\
FW & $0.591^{\mathrm{a}}$ & $0.665^{\mathrm{a}}$ & $0.717^{\mathrm{a}}$ \\
& D & -0.241 & $-0.874^{\mathrm{a}}$ & $-0.870^{\mathrm{a}}$ \\
& RW & $0.552^{\mathrm{a}}$ & $0.808^{\mathrm{a}}$ & $0.807^{\mathrm{a}}$ \\
$\mathrm{C}$ & LW $\%$ & $0.658^{\mathrm{a}}$ & $0.669^{\mathrm{a}}$ & $0.760^{\mathrm{a}}$ \\
& D & $-0.340^{\mathrm{a}}$ & $-0.864^{\mathrm{a}}$ & $-0.893^{\mathrm{a}}$ \\
& RW & $0.612^{\mathrm{a}}$ & $0.807^{\mathrm{a}}$ & $0.894^{\mathrm{a}}$ \\
\hline
\end{tabular}

${ }^{\text {a }}$ Significant at 0.01 level

The change in growth at approximately this age from the pith (ca. 60 years) was observed also as levelling off of density and LW\% increase in Siberian larch (Kärkkäinen 1978). In addition, the positive correlation between FL and $\mathrm{LW} \%$ in the two youngest age classes from the pith is in accordance with the observed correlations between growth rate and FL (Nekhaichuk and Bryantseva 1984; Use of larch as raw material for pulp and paper industry 1971) and growth rate and LW\% (Zhu et al. 1998), as in juvenile wood LW\% was higher the narrower the annual rings were.

FW followed similar axial and radial trends to the trends in FL: fibres were $6.6-7.6 \%$ and $31-32 \%$ narrower at the butt than at the other studied heights in the juvenile and mature wood, respectively. The FWs measured at the outermost heartwood in this study, 36-40 $\mu \mathrm{m}$, were similar to (Use of larch as raw material for pulp and paper industry 1971) or smaller than (Martinsson and Lesinski 2007) those found in larch trees grown in Siberia. The high variation observed in the FWs confirms the fact that the fibres of earlywood and latewood, not separated in this study, are of very different width, with the measured variation being from the minimum of $15 \mu \mathrm{m}$ of latewood to the maximum of $65 \mu \mathrm{m}$ of earlywood (Martinsson and Lesinski 2007). The negative correlations between $\mathrm{FW}$ and ring width in mature wood, up to age of 60 years from the pith, was comparable with the correlation between FL and ring width, but not in accordance with the earlier observations concerning growth rate and FW (Nekhaichuk and Bryantseva 1984), except with the observation made for Pinus banksiana Lamb. by Utunen (2008). However, the insignificant correlation between ring width and FW at the butt height was due to the exceptional ring width values (Luostarinen 2011). FW correlated with wood density in the two youngest age classes, in the class 1-5 years it was negative, while in the class 15-20 years from the pith it was positive. This indicated thin walls in the youngest wood, emphasised by the negative correlation between FW and LW\%. Positive correlation between density and FW at the age 15-20 years from the pith suggests an increase in fibre wall thickness (see Zobel and van Buijtenen 1989) when wood is maturing. However, in mature wood the relationship disappeared, possibly because of the observed widening of whole cells.

Coarseness was largest at the uppermost trunk height and radially at the outermost heartwood, both of which were expected on the basis of the measured FWs and FLs. Diameter of cells increases with maturity, mainly because of the increase in cell wall thickness (Zobel and van Buijtenen 1989), which in turn increases $C$. In this study, the $C$ values measured for larch varied more than those of $P$. abies (Zubizarreta et al. 2008) or Pinus ssp. (Karlsson 2006), as the lowest values of larch wood were below those measured for $P$. abies, while the highest values exceeded those found for Pinus ssp. As high $\mathrm{C}$ values may lead to formation
Table 5 Pearson correlation coefficients between fibre length (FL), fibre width (FW) and coarseness $(\mathrm{C})$, and density (D), average annual ring width (RW) and proportion of latewood (LW\%) by wood age class (years from the pith)

\footnotetext{
${ }^{\text {a }}$ Significant at 0.01 level

${ }^{\mathrm{b}}$ Significant at 0.05 level
}

\begin{tabular}{|c|c|c|c|c|c|c|}
\hline \multicolumn{2}{|c|}{ Wood age, years } & $1-5$ & $15-20$ & $21-40$ & $41-60$ & $61-73$ \\
\hline \multicolumn{2}{|l|}{$N$} & 48 & 48 & 49 & 37 & 10 \\
\hline \multicolumn{7}{|c|}{ Compared factors } \\
\hline \multirow[t]{3}{*}{ FL } & $\mathrm{D}$ & -0.096 & 0.279 & 0.011 & -0.071 & -0.261 \\
\hline & RW & 0.222 & $-0.783^{\mathrm{a}}$ & $-0.379^{\mathrm{a}}$ & $-0.472^{\mathrm{a}}$ & -0.437 \\
\hline & LW\% & $0.406^{\mathrm{a}}$ & $0.372^{\mathrm{a}}$ & -0.107 & -0.089 & -0.181 \\
\hline \multirow[t]{3}{*}{ FW } & $\mathrm{D}$ & $-0.305^{\mathrm{b}}$ & $0.323^{\mathrm{b}}$ & 0.158 & -0.022 & 0.017 \\
\hline & RW & $0.457^{\mathrm{a}}$ & $-0.498^{\mathrm{a}}$ & $-0.426^{\mathrm{a}}$ & $-0.525^{\mathrm{a}}$ & 0.176 \\
\hline & LW\% & $-0.447^{\mathrm{a}}$ & 0.198 & -0.037 & -0.037 & 0.059 \\
\hline \multirow[t]{3}{*}{$\mathrm{C}$} & $\mathrm{D}$ & -0.121 & $0.505^{\mathrm{a}}$ & $0.300^{\mathrm{b}}$ & -0.136 & 0.178 \\
\hline & RW & 0.073 & $-0.680^{\mathrm{a}}$ & $-0.483^{\mathrm{a}}$ & $-0.380^{\mathrm{b}}$ & 0.027 \\
\hline & LW\% & -0.071 & $0.453^{\mathrm{a}}$ & $0.297^{\mathrm{b}}$ & -0.123 & 0.174 \\
\hline
\end{tabular}


difficulties of paper sheets (Pulp and Paper Resources and Information Site 2010), the surface parts of larch logs from sawmills, being comprised mainly of extractive-poor sapwood (Côté and Timell 1967), are not suitable by themselves for paper products. Combining it with pulp made of juvenile wood of larch or with pulp made of another species (Hakkila et al. 1972; Valade 1998), both with smaller $\mathrm{C}$ values, seems to be necessary. The diameter of juvenile wood, poor for structural uses, in the studied planted larch trunks is high, even $20 \mathrm{~cm}$ (Luostarinen 2011) and it might be suitable for pulp manufacturing, as the extractive content of the wood decreases by increasing time from wood formation, in other words it is lower in the juvenile than in the mature heartwood (Côté and Timell 1967). Pulp including larch fibres is suitable for, e.g. packaging papers (Pulp and Paper Resources and Information Site 2010) because of the good tear strength of larch fibres (Hakkila et al. 1972; Nevalainen and Hosia 1969). On the other hand, mature heartwood should be used for structural products. Thus, the best way to exploit wood of planted larch may be to split the logs tangentially into parts for different usages. The outer parts of saw logs are commonly converted into sawmill chips for pulp production, but it could be profitable to pay extra attention to the separation of juvenile wood from mature heartwood by means of sawing patterns.

The proportion of the longest fibres in the larch trees studied increased towards the upper bole as well as towards the bark. The former result was also observed by Utunen (2008) for P. banksiana, while the latter one was also observed by Herman et al. (1998) for P. abies. The axial increase in the proportion of the longest fibres can be explained by the ageing of the apical meristem (Dodd 1988) and the radial increase by the maturation of the cambium and by the lower widening tendency of the annual rings in outer locations which enhances the lengthening of the fusiform initials (Bannan 1967; Dodd 1988). In addition to lengthening, ageing of the apical meristem affected the widening of the fibres as at the butt height and the width of the longest fibre class remained small; while higher up the trunk, cell enlargement was stronger. Widening length (Herman et al. 1998) and width ranges of fibres, both observed in this study, from pith to bark can be considered as a characteristic of wood maturation, the latter of which could be seen in all fibre classes except in the shortest one.

As a conclusion, the main trends in the variation in fibre dimensions in planted Siberian larch followed the trends of wood maturation and that caused by the ageing of the apical meristem: cell dimensions increased and ranges of both FL and FW widened radially outwards and axially upwards. Furthermore, differences between heights were smaller than between radial locations. Even though the random sampling direction from pith to bark may have increased the SE within a parameter, nevertheless the SE was quite small. A change in the correlations between the properties was observed at the ages of around 40-60 years from the pith, which may mean the start of senescence of the cambium, and, thus, that of the wood at this age from the pith. As the dimensions of the fibres in the outermost mature wood, particularly, were smaller in the studied planted larches than in larches grown in their natural provenances, the senescence of wood may start later if the growth rate is slower; the reason may also be in genetic factors, particularly as the studied trees represented only one origin, chosen for cultivation according to its good properties. Large variations, particularly radially, in fibre dimensions and thus in coarseness, together with large diameter of juvenile wood and colour difference between heartwood and sapwood, suggest that wood material from the different parts of logs of fast grown larch trees may be best suited for different usages.

Acknowledgements Mr. Samuli Heikkonen, Mikkeli University of Applied Sciences, is thanked for organising the wood material and Mr. Jarmo Pennala, School of Forest Sciences, University of Eastern Finland for sawing the wood strips and performing the fibre measurements.

\section{References}

Bannan MW (1967) Sequential changes in rate of anticlinal division, cambial cell length, and ring width in the growth of coniferous stems. Can J Bot 45:1359-1369

Chui YH, MacKinnon-Peters G (1995) Wood properties of exotic larch grown in eastern Canada and north-eastern United States. For Chron 71:639-646

Côté WA Jr, Timell TE (1967) Studies on larch arabinogalactan III. Distribution of arabinogalactan in tamarack. Tappi 50:285-289

Dodd RS (1988) Cyclophytic effects on wood structure in Pinus radiata D Don. II. Tracheid morphology. Can J For Res 18:413-420

Hakkila P, Nikki M, Palenius I (1972) Suitability of larch as pulpwood for Finland. Paperi ja Puu 1972 no. 2: 41-51, 54 $55,57-58$

Heikkonen S, Luostarinen K, Piispa K (2007) Kiln drying of Siberian larch (Larix sibirica) timber. Mikkelin ammattikorkeakoulu, A: Tutkimuksia ja raportteja-Research reports 26, 77 p + 1 app. ISBN 978-951-588-210-3. Available at: http://kirjasto. mikkeliamk/index.asp, ISBN 978-951-588-211-0

Herman M, Dutilleul P, Avella-Shaw T (1998) Intra-ring and inter-ring variations of tracheid length in fast grown versus slow-grown Norway spruces (Picea abies). IAWA J 19:3-23

Hutorščikov IS (1959) The physical properties and chemical composition of the wood of Larix sibirica. Forestry Abstracts 1961:022-03599

Isebrands JG, Hunt CM (1975) Growth and wood properties of rapidgrown Japanese larch. Wood Fiber 7:119-128

Kärkkäinen M (1978) Havaintoja iän vaikutuksesta lehtikuusen puuaineen tiheyteen. Summary: Observations on the effect of age on the basic density of larch wood. Silva Fennica 12:56-64

Karlman L, Mörling T, Martinsson O (2005) Wood density, annual ring width and latewood content in larch and Scots pine. Eurasian Journal of Forest Research 8:91-96 
Karlsson H (2006) Fibre guide. Fibre analysis and process applications in the pulp and paper industry. Lorentzen \& Wettre, Sweden, 120 p. ISBN 91-631-7899-0

Koizumi A, Takata K, Yamashita K, Nakada R (2003) Anatomical characteristics and mechanical properties of Larix sibirica grown in South-Central Siberia. IAWA J 24:355-370

Lindholm C-A, Kettunen J (1983) Paperimassan luonnehtiminen. In: Virkola NE (ed) Puumassan valmistus, Suomen paperiinsinööriyhdistyksen oppi- ja käsikirja II, Oy Turun Sanomat/ serioffset, Turku, pp. 1053-1106 (in Finnish). ISBN 95199117-1-5

Luostarinen K (2011) Density, annual growth and proportions of types of wood of planted fast grown Siberian larch (Larix sibirica) trees. Baltic Forest (in press)

Luostarinen K, Heikkonen S (2011) Effect of radial origin on final moisture content and gradient, casehardening, cracking and deformations of dried Siberian larch (Larix sibirica) timber. Eur J Wood Prod. doi:10.1007/s00107-010-0491-1

Lyck C, Bergstedt A (2007) Use and availability of larch wood in Northern Europe - a literature review. In: Bergstedt A, Lyck C (eds) Larch wood - a literature review, Forest and Landscape Working Papers 23/2007, Faculty of Life Sciences, University of Copenhagen, pp. 1-67. ISBN 978-87-7903-337-5

Martinsson O, Lesinski J (2007) Siberian larch. Forestry and timber in a Scandinavian perspective. Prinfo Accidenstryckeriet, $90 \mathrm{p}$. ISBN 978-91-633-1794-1

Nekhaichuk OG, Bryantseva ZE (1984) Effects of planting density and plantation age on anatomical structure of the wood of Larix sibirica. Forestry Abstracts 1985:046-00255

Nevalainen K, Hosia M (1969) The suitability of larch as fibre raw material Part II: larch as fibre raw material. Paperi ja Puu 51:503-510

Petrik AW (1968) Comparison of anatomical and pulping properties of some fast- and slow growing trees. For Prod J 18:62

Pulp and Paper Resources and Information Site (2010) Grades (types) of pulp. http://www.paperonweb.com/gradepl.htm. Accessed 20 June 2011

Saimovaara J (2001) Puuseppämestarien kokemuksia lehtikuusen käytöstä. In: Verkasalo E, Viitanen H (eds) Lehtikuusi puusepänteollisuuden raaka-aineena, Yhteistutkimushankkeen loppujulkaisu, Metsäntutkimuslaitoksen tiedonantoja 809, pp. 115-120. (in Finnish). ISBN 951-40-1782-X

Silander V, Lehtonen J, Nikkanen T (2000) Ulkomaisten havupuulajien menestyminen Etelä-Suomessa. Summary: Performance of exotic conifers in Southern Finland. Metsäntutkimuslaitoksen tiedonantoja 787. 127 p. ISBN 951-40-1754-4

Spångberg K (1999) Classification of Picea abies pulpwood according to wood and stand properties. Scand J For Res $14: 276-281$

Use of larch as raw material for pulp and paper industry (1971) Ministry of Pulp and Paper Industry of the USSR, Ministry of Higher and Secondary Education of the RSFSR, Order of Lenin Kirov Forest-Technical Academy, Leningrad, 102 p.

Utunen H (2008) Effects of stand density treatment on growth and wood and fiber properties of jack pine (Pinus banksiana Lamb.) grown in eastern Canada. M.S. thesis, Faculty of Forest Sciences, University of Joensuu, Joensuu, Finland, 33 p +1 app.

Valade JL (1998) The potential use of larch in the Canadian pulp and paper industry: a review. Pulp Paper Can 99:T459-462

Verkasalo E (1993) Lehtikuusitukkien laatu Suomessa. Summary: Technical quality of larch saw logs in Finland. Folia Forestalia 823. $27 \mathrm{p}$

Verkasalo E (2001) Johdanto. In: Verkasalo E, Viitanen H (eds) Lehtikuusi puusepänteollisuuden raaka-aineena, Yhteistutkimushankkeen loppujulkaisu, Metsäntutkimuslaitoksen tiedonantoja 809, pp. 5-14. (in Finnish). ISBN 951-40-1782-X

Vuokila Y (1960) Siperialaisten lehtikuusikoiden kehityksestä ja merkityksestä maamme metsätaloudessa. Summary: On development of Siberian larch stands and their importance to forestry in Finland. Commun Inst For Fenn 52:1-111

Zhang SY, Morgenstern EK (1995) Genetic variation and inheritance of wood density in black spruce (Picea mariana) and its relationship with growth: implications for tree breeding. Wood Sci Technol 30:63-75

Zhu J, Nakano T, Hirakawa Y (1998) Effect of growth on wood properties for Japanese larch (Larix kaempheri): differences of annual ring structure between corewood and outerwood. J Wood Sci 44:392-396

Zobel BJ, van Buijtenen JP (1989) Wood variation. Its causes and control, Springer Series in Wood Science, 363 p. ISBN 3-54050298-X

Zobel BJ, Sprague JR (1998) Juvenile wood in forest trees, Springer Series in Wood Science, 300 p. ISBN 3-54064032-0.

Zubizarreta GA, Peltola H, Pulkkinen P, Jaatinen R, Pappinen A (2008) Differences in fibre properties in cloned Norway spuce (Picea abies). Can J For Res 38:1071-1082 